\title{
Who Was John Howland and Why Was an Award Named After Him 50 Years Ago?
}

\author{
RUSSELL W. CHESNEY \\ Department of Pediatrics, University of Tennessee Health Science Center, LeBonheur Children's Medical \\ Center, Memphis, Tennessee 38103, U.S.A.
}

On May 5, 2002, Howard A. Pearson received the 52nd John Howland Award in its golden anniversary year (twice there were dual awardees). In his Centennial History of the American Pediatric Society (1), Howard Pearson stated that Howland awardees represent "a pantheon of modern American pediatrics." Given "for distinguished service to pediatrics," the Howland Award has been widely recognized for decades as the highest honor bestowed upon a pediatrician by the APS and may represent the most distinguished award in all of pediatrics.

As this award is celebrating its 50th year, the question posed in the title is relevant - who was John Howland, and why was he honored with an award? This commentary reviews these two questions and provides insight into a remarkable leader of American academic pediatrics.

Born in New York City in 1873 into an old New England family, John Howland spent his boyhood summers in Walpole, $\mathrm{NH}$, a small town north of Keene, $\mathrm{NH}$, on the Connecticut River. He excelled as both a student and an athlete, graduating from Phillips Exeter Academy, where he was a football star (2). At Yale University, he was an oarsman, an intercollegiate tennis champion, and was chosen by Skull and Bones. He selected a career in medicine and graduated from New York University School of Medicine in 1897. He felt that he needed to be more fully prepared, so he pursued a second M.D. degree at Cornell Medical College, graduating in 1899.

During his internship at the Presbyterian Hospital of New York from 1899 to 1900 , he became fascinated with the diseases of childhood. He spent time at the New York Foundling Hospital, where he came under the influence of L. Emmett Holt, Sr., a major figure in American pediatrics (3). Holt authored an important textbook, Diseases of Infants and Children, which is still published today (4).

The center of medical knowledge at the onset of the 20th century was Europe, particularly the schools of Vienna and Berlin. From 1900 to 1901, Howland studied at both centers. Indeed, his first paper concerning "The Glomerulonephritis of Typhus Abdominalis" was published in German (6). After his second year of training, Howland joined Holt in practice in

Received June 17, 2002; accepted July 24, 2002.

Correspondence: Russell W. Chesney, M.D., Department of Pediatrics, University of Tennessee Health Science Center, LeBonheur Children's Medical Center, 50 N. Dunlap, Room 306, Memphis, TN 38103, U.S.A.; e-mail: rchesney@utmem.edu

Presented at the 2002 Annual Meeting of the Pediatric Academic Societies, Baltimore, Maryland, U.S.A.

DOI: 10.1203/01.PDR.0000052080.78446.91
New York and taught in three training hospitals - Presbyterian, The Foundling Hospital, and Babies Hospital. He remained in this active, academic practice from 1901 to 1910. In 1910, Howland accepted the call from Washington University in St. Louis, MO, to serve as chair of pediatrics. While his stay there was brief, he began to develop his concept of an academic pediatric department.

In 1911, he moved to the New Harriet Lane Home for Children at the Johns Hopkins Hospital in Baltimore, MD (Fig. 1). He remained there, as chair, until his early death in 1926. It was while he was there that he developed his seminal contribution to pediatrics - the formation of a department in which all faculty members were full-time academics. This paradigm was accepted by Johns Hopkins and had enormous influence on the development of the modern American pediatric department. He also insisted that all his faculty members spend at least $50 \%$ of their time in inquiry-based research. With these two concepts - a full-time faculty and a focus on research - the model for academic pediatrics was born.

Howland surrounded himself with a remarkable group of brilliant young men. In his department at Hopkins, his protégés went on to other schools, emulated his theories of pediatric academic development, and spread his paradigm. Some of these faculty members who went on to leadership positions, chairmanships, and to establish centers of research are indicated below. The legendary Kenneth Blackfan went to Children's Hospital in Boston and Harvard. McKim Marriott, a superb chemist, went to Washington University at St. Louis. Edwards A. Park first went to Yale and later returned to Hopkins succeeding Howland at Hopkins and the Harriett Lane Home. Grover Powers followed Park to Yale and became a superb chair. Wilburt C. Davison went to Duke, where he later became a long-term dean. Samuel Clausen was the first chair at the University of Rochester. Horton Caspairo went to Vanderbilt. Benjamin Kramer, another superb chemist and developer of microchemical techniques, as well as student of bone growth, became the chair at Brooklyn Jewish Hospital, an affiliate of the Long Island College of Medicine. This later became the State University of New York-Downstate Medical Center. James L. Gamble left Hopkins for Boston Children's/Harvard and was a remarkable figure in the development of fluid and electrolyte physiology. This list is not exhaustive, but what is important is that this exodus of Howland's descendants was occurring during the era in which the Abraham Flexner report had its greatest influence. In his 


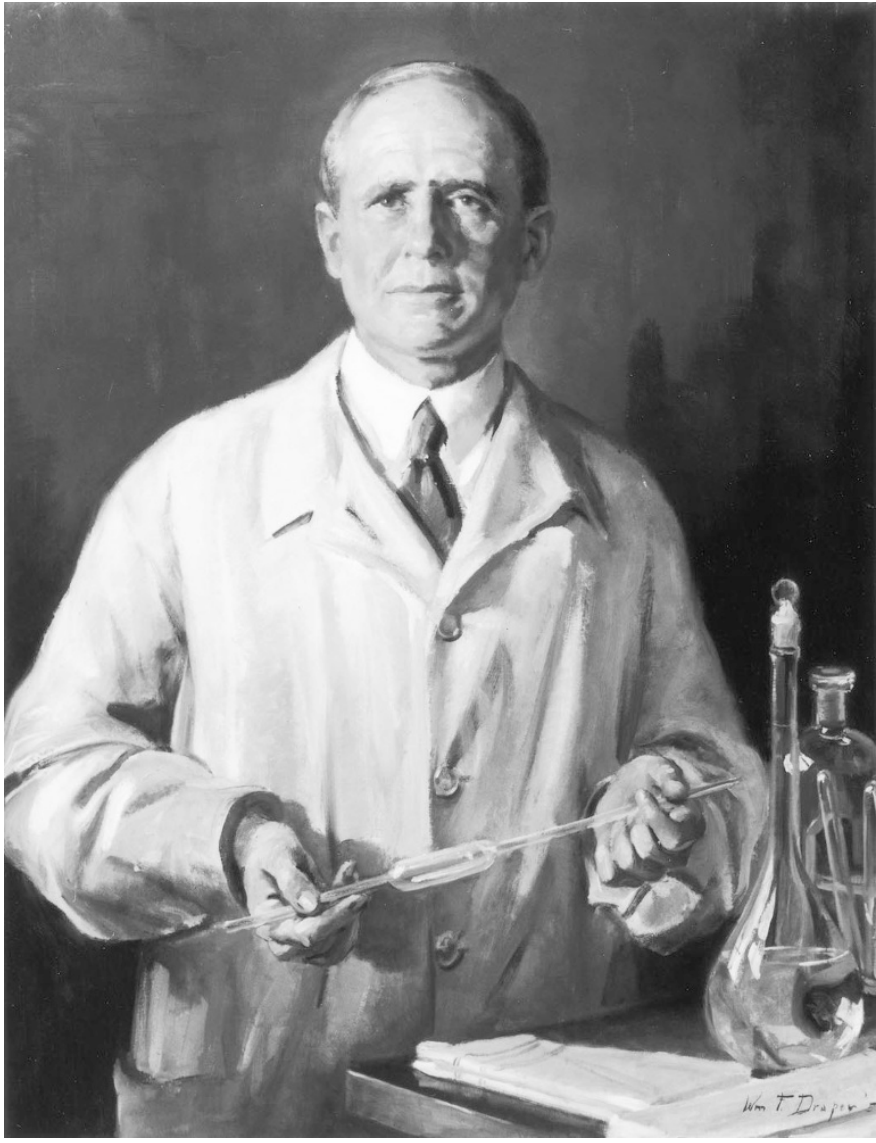

Figure 1. John Howland 1873-1926. Portrait by William F. Draper. Printed with permission of the Alan Mason Chesney Medical Archives of the Johns Hopkins Medical Institutions.

important book, Kenneth Ludmerer captures the excitement during the 15 years following Flexner's report (7).

But what of the man John Howland, and what was he like? First, he came from old New England roots, in which he took pride. An ancestor, John Howland of Finstanton in East Anglia, north and east of London, England, was a Puritan. He, like many East Anglians, felt deeply about his denomination and had been baptized in the cathedral in Ely, which had been desecrated by the crown. He and his fellow Puritans (who were also called Pilgrims) feeling the persecution of the Stuart kings left Plymouth on the ship Mayflower, headed for the New World (8). During a bad storm, young John Howland the Puritan fell overboard. Miraculously, he was able to grab a trailing topsail halyard and was pulled to safety with a boat hook (T DeWitt, personal communication, 2002). Family legend ${ }^{1}$ says that he was "inebriated," but John Howland, the pediatrician, was dubious. John Howland, the Puritan, was indentured to Governor Carver of the Plymouth Colony. Again,

${ }^{1}$ Dr. Thomas deWitt, a 12th-generation descendent of John Howland the Puritan, provided this inside information. "After a lengthy conversation with my resident Howlan historian - my mother-I have gleaned the following tidbits. John ran up on the Mayflower deck and fell overboard. He grabbed on to a trailing halyard and was saved. Given these circumstances and his appropriate actions in such a situation, I think it is unlikely that he was inebriated. In regard to his status, he was considered as one of Governor Carver's family, perhaps as an indentured servant. He was described as industrious, demonstrating sound judgment and business capacity—not unlike his pediatrician descendent - and was a key figure in the founding of the Plymouth Colony."
John Howland the pediatrician stoutly denied this status, preferring to feel that his ancestor was adopted (2). At any rate, he was a key figure in establishing the Plymouth Colony.

Howland was acknowledged to be a superb diagnostician and bedside teacher. He was an elegant editor and coauthored three editions of Holt's textbook, the seventh through ninth editions (4). Davison (2) stated that Howland wrote with great clarity about the topics he covered. When the etiology and pathogenesis were unknown, this Howland clearly stated. When one reads other textbooks of the era, his honesty is refreshing. Howland clearly enjoyed bedside teaching and was a gifted performer. He was also demanding of his colleagues, residents, and students. Davison stated that he was a mixture of "Winston Churchill, Esculapius (sic), and (the) Czar of Russia" (2).

As with the legendary Yankee, Howland was frugal to a fault. His cost-saving measures were the subject of many an anecdote (2), and a few examples are illustrative. Howland never purchased an automobile, preferring to obtain rides to work with colleagues. He wore the same felt hat for 17 years and cleaned it by pouring gasoline through it. When asked why, he stated that gasoline at 17 cents per gallon was far cheaper than hat cleaning at $\$ 2.50$ per year. At APS meetings, he frequently ate at an Atlantic City restaurant, Child's Restaurant, whose menu listed the cost of the food in one column and the available calories per item in another. Always mindful of calories per dollar, he generally ate the same mealpancakes, syrup, and sausage.

Howland was a hard worker. He always worked 6 days per week and expected this of his protégés and students. He always rested on Sunday, which, weather permitting, he devoted to golf. He played 18 holes in the morning, 18 holes in the afternoon, and a few more holes until the sun fell. He was also known to skip afternoon sessions at APS meetings for golfing with friends. One memorable occasion was at the 1914 meeting at the Red Lion Inn in Stockbridge, MA, and its wonderful course (1). Recall at this time, attendance was limited and any absence would be noticed. On one occasion, Howland passed by the tennis courts in the inner courtyard of the Johns Hopkins Hospital and near the Harriet Lane Home. A game was in progress, and he was persuaded to play. Although he had not picked up a tennis racket in 3 decades, he hit his shots back cleanly and won the match.

Howland's research questions related to the major childhood illnesses of his era: rickets, diarrhea, and acidosis. With Marriott, he showed that the acidosis in "cholera infantum" was not due to a toxin but rather to the excessive loss of bicarbonate in the stool. With Kramer and Park, he showed (9) that tetany was due to alkalosis and hypocalcemia (10). He also demonstrated with colleagues that both hypocalcemia and hypophosphatemia are found in rickets (11).

In 1951, the APS developed an award designated the John Howland Award, which was to be given "to honor those who, by their contributions to pediatrics, have aided in its advancement." Of the 52 winners, 11 were taught or directly influenced by John Howland (Table 1).

Howland, a teetotaler, died of cryptogenic cirrhosis at age 53 , perhaps related to his typhoid fever with jaundice in 
college, and pediatrics lost a giant figure. He was the first and obvious choice to have a medal named in his honor because:

1. He developed the first full-time pediatric department in the United States.

2. He stressed the value of a full-time clinician scientist faculty member with protected time.

3. His belief that scientific progress in pediatrics should be built on integration with the basic sciences, particularly biochemistry.

4. He studied diarrhea, acidosis, rickets, tetany, and published 60 papers.

5. He was a mentor, role model, and father figure to prominent leaders, many of whom received his medal.

Table 1. Awardees of the John Howland Award influenced or taught by Howland

$\begin{array}{ll}\text { Edwards A. Park } & \text { Lawson Wilkins } \\ \text { Grover E. Powers } & \text { L. Emmett Holt, Jr. } \\ \text { James L. Gamble } & \text { Martha H. Eliot (student) } \\ \text { Ethel C. Dunham } & \text { Helen B. Taussig (student) } \\ \text { Daniel C. Darrow } & \text { Irvine McQuarrie } \\ \text { Rustin McIntosh } & \end{array}$

6. His disciples led academic pediatrics until the mid-1950s.

Imagine what our field would have missed if the young Puritan had not grasped that rope in a sea voyage during the autumn of 1620 and been pulled to safety.

\section{REFERENCES}

1. Pearson HA 1988 The Centennial History of the American Pediatric Society 1888 1988. Yale University Printing Service, New Haven, CT

2. Davison WC 1957 John Howland (1873-1926). In: Veeder BS (ed) Pediatric Profiles. C.V. Mosby, St. Louis, pp 161-174

3. Park EA, Mason HH 1957 Luther Emmett Holt (1855-1924). In: Veeder BS (ed) Pediatric Profiles. C.V. Mosby, St. Louis, pp 33-60

4. Holt LE, Howland J 1927 Diseases of Infancy and Childhood. Appleton and Company, New York

5. Deleted in proof.

6. Howland J 1901 Glomerulonephritis bei typhus abdominalis. Virchow Arch $163: 360-365$

7. Ludmerer KL 1999 A Time To Heal. Oxford Press, New York

8. McCrum R, Cran W, MacNeil R 1986 The Story of English. Penguin Books, New York

9. Howland J, Marriott W 1916 Acidosis occurring with diarrhea. Am J Dis Child 11:309-319

10. Howland J, Marriott W 1918 Observations upon the calcium content of the blood in infantile tetany and the effect of treatment by calcium. Q J Med 11:289-296

11. Howland J, Kramer B 1921 Calcium and phosphorus in the serum in relation to rickets. Am J Dis Child 22:105-119 